\title{
Viral hepatitis and HIV-associated tuberculosis: Risk factors and TB
} treatment outcomes in Thailand

\author{
Chawin Sirinak ${ }^{1}$, Wanitchaya Kittikraisak ${ }^{2}$, Duangporn Pinjeesekikul ${ }^{1}$, \\ Pricha Charusuntonsri ${ }^{1}$, Phinai Luanloed ${ }^{1}$, La-ong Srisuwanvilai ${ }^{1}$, \\ Sriprapa Nateniyom ${ }^{3}$, Somsak Akksilp ${ }^{4}$, Sirirat Likanonsakul ${ }^{5}$, \\ Wanchai Sattayawuthipong ${ }^{6}$, Channawong Burapat ${ }^{2}$ and Jay K Varma*2,7
}

\author{
Address: ${ }^{1}$ Department of Health, Bangkok Metropolitan Administration, Bangkok, Thailand, ${ }^{2}$ Thailand Ministry of Public Health - U.S. Centers \\ for Disease Control and Prevention Collaboration, Nonthaburi, Thailand, ${ }^{3}$ Thailand Ministry of Public Health, Nonthaburi, Thailand, ${ }^{4}$ Office of \\ Disease Prevention and Control 7, Ubon-ratchathani, Thailand, ${ }^{5}$ Bamrasnaradura Infectious Diseases Institute, Nonthaburi, Thailand, 6 Phuket \\ Provincial Health Office, Phuket, Thailand and ${ }^{7}$ U.S. Centers for Disease Control and Prevention, Atlanta, USA \\ Email: Chawin Sirinak - sirinak@hotmail.com; Wanitchaya Kittikraisak - WanitchayaK@th.cdc.gov; \\ Duangporn Pinjeesekikul - oduangporn@yahoo.com; Pricha Charusuntonsri - pcharu@gmail.com; Phinai Luanloed - pinaill@yahoo.com; La- \\ ong Srisuwanvilai - laong@bma-gap.or.th; Sriprapa Nateniyom - nateniyoms@yahoo.com; Somsak Akksilp - akksilp_s@yahoo.com; \\ Sirirat Likanonsakul - wirojmankhatitham@yahoo.com; Wanchai Sattayawuthipong - wanchaig@health.moph.go.th; \\ Channawong Burapat - ChannawongB@th.cdc.gov; Jay K Varma* - jvarma@cdc.gov \\ * Corresponding author
}

Published: 18 July 2008

BMC Public Health 2008, 8:245 doi:10.1 I86/147|-2458-8-245
Received: 7 May 2008

Accepted: 18 July 2008

This article is available from: http://www.biomedcentral.com//47I-2458/8/245

(C) 2008 Sirinak et al; licensee BioMed Central Ltd.

This is an Open Access article distributed under the terms of the Creative Commons Attribution License (http://creativecommons.org/licenses/by/2.0), which permits unrestricted use, distribution, and reproduction in any medium, provided the original work is properly cited.

\begin{abstract}
Background: The occurrence of tuberculosis (TB), human immunodeficiency virus (HIV), and viral hepatitis infections in the same patient poses unique clinical and public health challenges, because medications to treat TB and HIV are hepatotoxic. We conducted an observational study to evaluate risk factors for $\mathrm{HBsAg}$ and/or anti-HCV reactivity and to assess differences in adverse events and TB treatment outcomes among HIV-infected TB patients.

Methods: Patients were evaluated at the beginning, during, and at the end of TB treatment. Blood samples were tested for aspartate aminotransferase (AST), alanine aminotransferase (ALT), total bilirubin (BR), complete blood count, and CD4+ T lymphocyte cell count. TB treatment outcomes were assessed at the end of TB treatment according to international guidelines.

Results: Of 769 enrolled patients, $752(98 \%)$ had serologic testing performed for viral hepatitis: $70(9 \%)$ were reactive for $\mathrm{HBsAg}, 237$ (3I\%) for anti-HCV, and $472(63 \%)$ non-reactive for both markers. At the beginning of TB treatment, $18(26 \%)$ patients with $\mathrm{HBsAg}$ reactivity had elevated liver function tests compared with 69 (15\%) patients non-reactive to any viral marker $(p=0.02)$. At the end of TB treatment, $493(64 \%)$ were successfully treated. Factors independently associated with $\mathrm{HBsAg}$ reactivity included being a man who had sex with men (adjusted odds ratio [AOR], 2.I; $95 \%$ confidence interval [Cl], I.I-4.3) and having low TB knowledge (AOR, I.8; $\mathrm{Cl}, \mathrm{I} .0-3.0)$. Factors most strongly associated with anti-HCV reactivity were having injection drug use history (AOR, I2.8; $\mathrm{Cl}, 7.0-23.2$ ) and living in Bangkok (AOR, I5.8; $\mathrm{Cl}, 9.4-26.5)$. The rate of clinical hepatitis and death during TB treatment was similar in patients $\mathrm{HBsAg}$ reactive, anti-HCV reactive, both $\mathrm{HBsAg}$ and anti-HCV reactive, and non-reactive to any viral marker.

Conclusion: Among HIV-infected TB patients living in Thailand, markers of viral hepatitis infection, particularly hepatitis $\mathrm{C}$ virus infection, were common and strongly associated with known behavioral risk factors. Viral hepatitis infection markers were not strongly associated with death or the development of clinical hepatitis during TB treatment.
\end{abstract}




\section{Background}

Over nine million new cases of tuberculosis (TB) occur annually throughout the world. While most of these cases can safely and effectively be treated, complications can occur during TB treatment, because of anti-TB drug resistance, poor adherence, drug-drug interactions, and toxicity.[1] Liver toxicity is a particularly common side effect that is strongly associated with three of the four anti-TB drugs included in the most widely accepted regimen.[2,3] The burden of $\mathrm{TB}$ continues to rise in some regions of the world, because of the human immunodeficiency virus (HIV) epidemic. This TB/HIV syndemic has also increased the clinical complexity of managing patients. Medications used to prevent opportunistic infections or treat HIV are often hepatotoxic, and opportunistic infections may involve the liver. [4-6]

The epidemics of hepatitis $\mathrm{B}$ and/or $\mathrm{C}$ virus infection (HBV and HCV, respectively) involve many of the populations that are at risk of HIV infection. This is particularly true in Eastern Europe and Asia, where injection drug use is a potent driver of the HIV epidemic. [7-9] The occurrence of TB, HIV, and viral hepatitis infection in the same patient poses unique challenges to clinicians and public health officials. A major concern is that such patients may acquire clinical hepatitis during treatment with the firstline $\mathrm{TB}$ or HIV regimens available in most of the world. One study in HIV-infected TB patients demonstrated a doubling in liver enzyme levels in $14 \%$ of patients with HBV and $12 \%$ of patients with HCV infection, although few had symptomatic hepatitis.[10] Another small study found that 5 of 11 (45\%) patients with both HCV and HIV infection developed drug-induced hepatitis during TB treatment; the risk of hepatitis was over 3 times greater than in those with HIV infection alone and over 14 times greater than in those with neither HIV nor HCV infection.[11]

Thailand is one of 22 World Health Organization (WHO)-designated "high burden" TB countries and has a generalized HIV epidemic.[12,13] Over $15 \%$ of TB patients in Thailand have HIV infection.[14] Among blood donors born before the introduction of universal hepatitis B vaccination in 1992, the percentage of Thais with hepatitis B surface antigen (HBsAg) and antibodies to HCV (anti-HCV) ranged from $4 \%$ to $13 \%[15]$ and $1 \%$ to $4 \%$ [15-17], respectively. Little is known about the burden of HBV and HCV infection in HIV-infected TB patients, or the impact of these infections on TB treatment outcomes in Thailand. We conducted an observational study in four provinces in Thailand to evaluate the prevalence of and risk factors for HBsAg and/or anti-HCV reactivity among HIV-infected TB patients undergoing TB treatment. We also evaluated the impact of HBV and HCV infections on adverse events during TB treatment and on final TB treatment outcome.

\section{Methods}

\section{Study setting and population}

We conducted a multi-center, observational, prospective cohort study among HIV-infected TB patients at public TB treatment facilities in Bangkok, Phuket, and Ubon Ratchathani provinces and at the national infectious diseases disease referral hospital (Bamrasnaradura Infectious Diseases Institute) in Nonthaburi province from May 2005 to September 2006. The study population included adults aged $\geq 18$ years with documented HIV infection who were diagnosed with active TB disease according to national TB program guidelines[18], registered for TB treatment at one of the participating facilities, and received anti-TB therapy (for this episode of TB) for $<4$ weeks before study enrollment. We excluded prisoners and pregnant women. Patients with previous history of TB treatment were eligible for the study. Patients providing written informed consent were followed from TB treatment initiation to the end of TB treatment. For this study, patients received usual care for TB, HIV, and other diseases, and no health-related interventions were performed. In Thailand, patients with no prior history of TB treatment usually receive isoniazid, rifampin, ethambutol, and pyrazinamide. When prescribed anti-retroviral therapy, HIV-infected patients usually receive stavudine, lamivudine, and nevirapine; in patients with $\mathrm{TB}$, efavirenz is recommended as a substitute for nevirapine.

\section{Data collection and laboratory studies}

Patients had three study visits during TB treatment: at the beginning of treatment, at the end of the intensive phase of TB treatment (usually two months into treatment), and at the end of TB treatment (usually six months after treatment initiation). At the beginning of treatment, patients were interviewed using standardized study forms that asked about demographic characteristics, past and present medical history, knowledge and attitudes related to TB and HIV, and sex and drug use history. At every study visit, patients received a physical examination and were asked about medications taken and any adverse events experienced since their previous visit. Medical records were reviewed for results of examinations or tests performed between study visits. Adverse events were defined as any health-related problem that occurred during study followup, that was plausibly related to TB or HIV treatment, and that necessitated a physician evaluation. For adverse events, a definition of "liver disease" was applied to any patient who was diagnosed by a physician has having hepatitis, jaundice, or cirrhosis.

At the beginning of treatment, blood samples were tested for HBsAg and anti-HCV. No other tests of viral hepatitis 
infection were performed. These serologic tests for viral hepatitis markers were performed at the health facility enrolling the patient or, if necessary, at a centralized government laboratory in each respective province. For $\mathrm{HBsAg}$, the following assays were used: Enzygnost (Dade Behring, Germany); AxSym HBsAg, version 2 (Abbott, Abbott Park, USA). For anti-HCV, the following assays were used: anti-HCV ELISA (Abbott, Abbott Park, USA); AxSym, version 3.0 (Abbott, Abbott Park, USA); HCV TriDot (J. Mitra, India). In addition, blood samples were tested for aspartate aminotransferase (AST), alanine aminotransferase (ALT), total bilirubin (BR), complete blood count, and CD4+ T lymphocyte (CD4) cell count at the beginning of treatment. In these laboratories, the upper limit of normal for AST was 35 units/L, ALT 33 units/L, and total bilirubin $1 \mathrm{mg} / \mathrm{dL}$. Sputum and specimens from extra-pulmonary sites were collected for acid fast bacilli (AFB) smear, mycobacterial culture, identification, and drug-susceptibility testing.

$\mathrm{TB}$ treatment outcomes were assessed at the end of $\mathrm{TB}$ treatment according to the national $\mathrm{TB}$ program and WHO guidelines; successful TB treatment comprised both cure and completed treatment.[18] For patients recorded as defaulting during TB treatment, we reviewed government vital registration data to determine whether patients died within 90 days of stopping TB treatment; such patients were re-classified as deaths during TB treatment.

\section{Statistical analysis}

We calculated a TB knowledge score as the sum of correct answers to seven questions about TB and TB treatment; these questions were derived from information routinely provided to patients as part of the national TB program. High TB knowledge was defined as having a TB knowledge score equal to or greater than the median score of the study population. Similarly, we calculated a TB stigma score as the sum of four questions about TB stigma that a patient answered affirmatively (e.g., "Would you share a meal with someone with TB?"). Low TB stigma was defined as having a TB stigma score less than the median score of the study population.

We calculated proportions to describe demographic characteristics, clinical features, and adverse events. We analyzed groups stratified by viral hepatitis marker (HBsAg, anti-HCV, and both HBsAg and anti-HCV). However, patients were not broken down into 3 mutually exclusive categories: a patient who was positive for both markers was in the HBsAg analysis, the HCV analysis, and the "both" HBsAg and anti-HCV analysis. To identify characteristics predictive of these viral hepatitis markers, we first identified factors associated with each marker at $\mathrm{p}=0.20$ in univariate analysis and then constructed multivariate logistic regression models. For each multivariate analysis, we fitted a full model and a parsimonious model using a backward stepwise variable selection procedure. Findings from both models were similar; therefore, we reported estimates from the full model. There were 732,736 , and 740 patients included in the HBsAg, anti-HCV, and both HBsAg and anti-HCV analyses, respectively.

To determine whether different viral hepatitis markers were associated with different TB treatment outcomes, we analyzed the likelihood of death or a composite end point of death and default vs. TB treatment success, adjusted for factors associated with $\mathrm{TB}$ treatment outcome at $\mathrm{p}=0.20$ in univariate analysis. We fitted full and parsimonious models. Findings from both models were similar; we reported the estimates from the former. A subset of patients with culture-confirmed TB (defined as having any specimen culture-positive for MTB) was also analyzed.

For analysis of risk factors for viral hepatitis or the outcomes of TB treatment, we excluded 17 patients with unavailable viral hepatitis serology test results. In all analyses, we defined a two-sided p-value of $\leq 0.05$ as statistical significance. We performed all analyses using Stata software version 8.0 (StataCorp LP, College Station, TX, U.S.A.).

\section{Ethical review}

This study was approved by the ethical review committees of the Bangkok Metropolitan Administration, the Thailand Ministry of Public Health, and the U.S. Centers for Disease Control and Prevention.

\section{Results \\ Characteristics and clinical features}

We enrolled 849 HIV-infected TB patients in the study. Excluding those whose diagnosis of TB was subsequently changed (e.g., cultures grew non-tuberculosis mycobacteria), $769(91 \%)$ were retained in the analysis (Figure 1). Of these, 752 (98\%) had serologic tests for viral hepatitis infection. Seventy (9\%) patients were reactive for $\mathrm{HBsAg}$, 237 (31\%) for anti-HCV, and 472 (63\%) non-reactive for both HBsAg and anti-HCV. Twenty-seven (4\%) patients were reactive for both HBsAg and anti-HCV. The median age of patients was 34 (interquartile range [IQR], 30-41) years, and most patients were male and employed (Table 1). Of the 769 patients, $461(60 \%)$ had pulmonary $\mathrm{TB}$, and $667(87 \%)$ had not previously been treated for TB.

The median AST among patients reactive to $\mathrm{HBsAg}$, antiHCV, both HBsAg and anti-HCV, and neither were 58 (IQR, 35-92), 40 (IQR, 30-75), 59 (IQR, 36-105), and 58 (IQR, 40-101) units/L, respectively. The median ALT among patients reactive to $\mathrm{HBsAg}$, anti-HCV, both $\mathrm{HBsAg}$ and anti-HCV, and neither were 33 (IQR, 22-54), 28 (IQR, 17-50), 37 (IQR, 20-63), and 37 (IQR, 24-52) units/L, respectively. The median bilirubin level among 


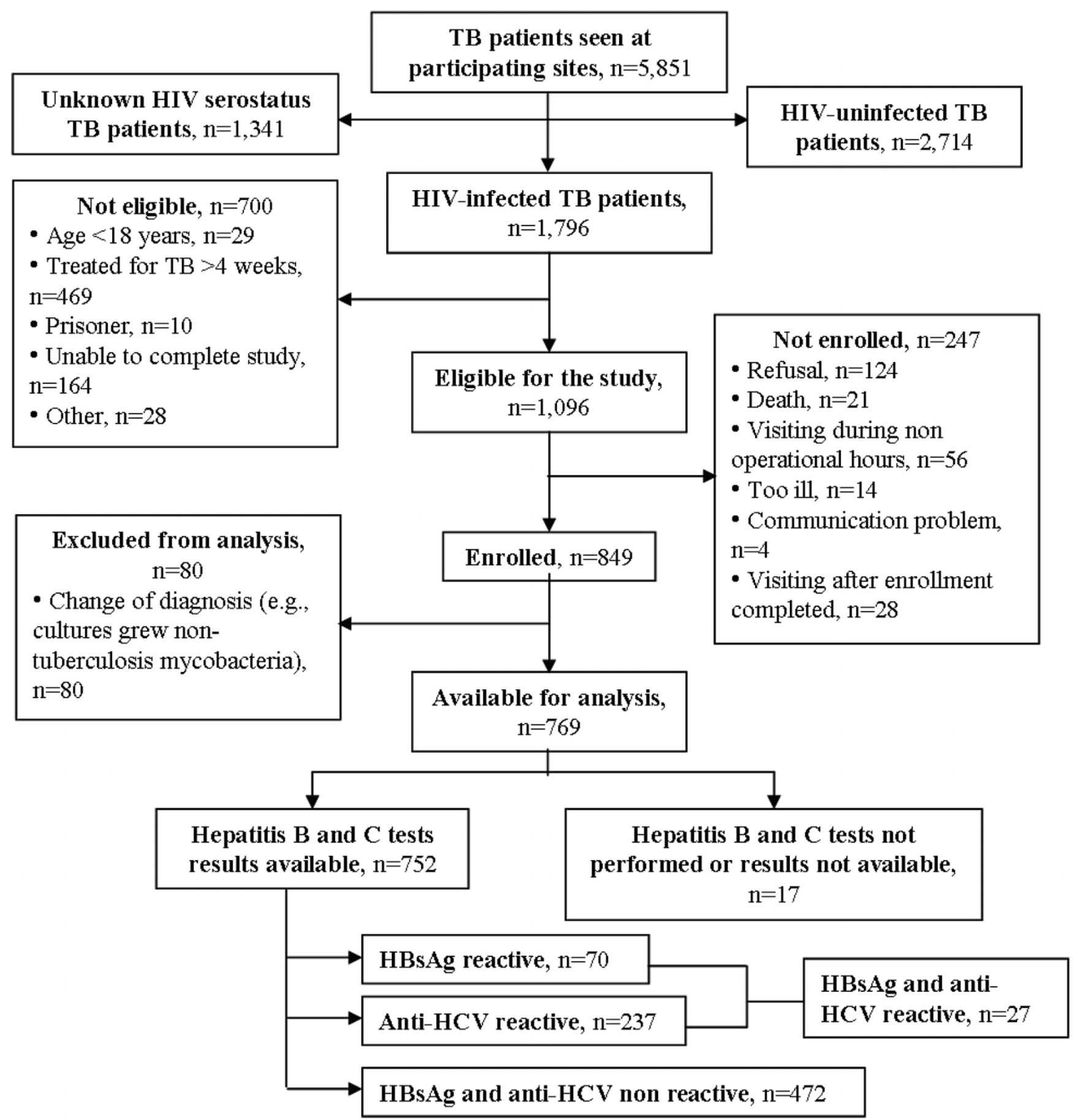

Figure I

Enrollment of HIV-infected TB patients in the study.

patients reactive to $\mathrm{HBsAg}$, anti-HCV, both $\mathrm{HBsAg}$ and anti-HCV, and neither were 0.6 (IQR, 0.4-1.1), 0.5 (IQR, $0.3-0.9$ ), 0.6 (IQR, 0.4-1.3), and 0.7 (IQR, 0.5-1.1) mg/ $\mathrm{dL}$, respectively. Of the 759 with available liver function test results, elevated levels were found in 18/70 (26\%) patients with HBsAg ( $\mathrm{p}=0.02$ compared to non-reactive), $37 / 236(16 \%)$ patients with HCV ( $\mathrm{p}=0.93$ compared to non-reactive), $6 / 27(22 \%)$ patients with both $(\mathrm{p}=0.42$ 
Table I: Characteristics and clinical features of HIV-infected TB patients at the time of TB diagnosis, stratified by markers for viral hepatitis infection.

\begin{tabular}{|c|c|c|c|c|c|c|}
\hline \multirow{2}{*}{$\begin{array}{l}\text { Characteristics and clinical } \\
\text { features }\end{array}$} & \multirow{2}{*}{$\begin{array}{l}\text { All patients } \\
(n=769)\end{array}$} & \multirow{2}{*}{$\begin{array}{c}\text { Non-reactive for } \mathrm{HBsAg} \\
\text { and anti-HCV } \\
(n=472)\end{array}$} & \multicolumn{3}{|c|}{ Reactive for } & \multirow{2}{*}{$\begin{array}{l}\text { Unknown } \\
(n=17)\end{array}$} \\
\hline & & & $\begin{array}{l}\text { Only HBsAg } \\
\qquad(n=43)\end{array}$ & $\begin{array}{l}\text { Only anti-HCV } \\
(n=210)\end{array}$ & $\begin{array}{l}\mathrm{HBsAg} \text { and anti-HCV } \\
\qquad(\mathrm{n}=27)\end{array}$ & \\
\hline \multicolumn{7}{|l|}{ Characteristics } \\
\hline Age $>34$ years old & $380(49)$ & $221(47)$ & $21(49)$ & $115(55)$ & $12(44)$ & II (65) \\
\hline Male & $538(70)$ & $294(62)$ & $32(74)$ & $175(83)$ & $25(93)$ & $12(71)$ \\
\hline$>6$ th grade education & $300(39)$ & $182(39)$ & $20(47)$ & $83(40)$ & $9(33)$ & $6(35)$ \\
\hline Employed & $452(59)$ & $298(63)$ & $28(65)$ & $103(49)$ & $16(59)$ & $7(4 I)$ \\
\hline Single & $237(31)$ & $125(27)$ & $14(33)$ & $83(40)$ & $10(37)$ & $5(29)$ \\
\hline Body mass index $<18.5$ & $443(58)$ & $270(57)$ & $24(56)$ & $116(55)$ & $21(78)$ & $12(7 \mid)$ \\
\hline Low TB knowledge & $592(77)$ & $369(78)$ & $27(63)$ & $162(77)$ & $21(78)$ & $13(77)$ \\
\hline High TB stigma & $500(65)$ & $294(62)$ & $26(61)$ & $146(70)$ & $20(74)$ & $14(82)$ \\
\hline Live in Bangkok & $177(23)$ & $37(8)$ & $4(9)$ & $122(58)$ & $13(48)$ & I (6) \\
\hline \multicolumn{7}{|l|}{ TB disease classification } \\
\hline Pulmonary TB & $46 I(60)$ & $261(55)$ & $21(49)$ & | 46 (70) & $21(78)$ & $12(7 \mid)$ \\
\hline Smear positive & $283(37)$ & $169(36)$ & $13(62)$ & $80(38)$ & $11(52)$ & $10(59)$ \\
\hline Abnormal chest $\mathrm{x}$-ray & $415(54)$ & $233(49)$ & $17(81)$ & $134(64)$ & $20(95)$ & $11(65)$ \\
\hline Extra-pulmonary TB & $230(30)$ & $168(36)$ & $16(37)$ & $37(18)$ & $5(19)$ & $4(24)$ \\
\hline $\begin{array}{l}\text { Pulmonary and extra- } \\
\text { pulmonary TB }\end{array}$ & $78(10)$ & $43(9)$ & $6(14)$ & $27(13)$ & I (4) & I (6) \\
\hline \multicolumn{7}{|l|}{ TB treatment } \\
\hline $\begin{array}{l}\text { Registered for TB treatment } \\
\text { as new case }\end{array}$ & $667(87)$ & $424(90)$ & $35(8 I)$ & $173(82)$ & $19(70)$ & $16(94)$ \\
\hline $\begin{array}{l}\text { Received standard or } \\
\text { extended HRZE }\end{array}$ & $665(87)$ & $430(91)$ & $35(8 I)$ & $168(80)$ & $17(63)$ & $15(88)$ \\
\hline $\begin{array}{l}\text { DOT by healthcare worker } \\
\text { or village health volunteer }\end{array}$ & $246(32)$ & $100(21)$ & $17(40)$ & $107(5 \mathrm{I})$ & $14(52)$ & $8(47)$ \\
\hline \multicolumn{7}{|l|}{$\begin{array}{l}\text { Drug and alcohol use, and } \\
\text { incarceration history }\end{array}$} \\
\hline Currently smoke & $205(27)$ & $94(20)$ & $10(23)$ & $86(4 I)$ & $10(37)$ & $5(29)$ \\
\hline History of alcohol use & $538(70)$ & $317(67)$ & $30(70)$ & $159(76)$ & $20(74)$ & $12(7 I)$ \\
\hline $\begin{array}{l}\text { History of methamphetamine } \\
\text { use }\end{array}$ & $304(40)$ & $146(31)$ & $11(26)$ & $128(61)$ & $15(56)$ & $4(24)$ \\
\hline History of marijuana use & $267(35)$ & $118(25)$ & II (26) & $120(57)$ & $13(48)$ & $5(29)$ \\
\hline History of ketamine use & $26(3)$ & II (2) & I (2) & II (5) & I (4) & $2(12)$ \\
\hline History of ecstasy use & $32(4)$ & $16(3)$ & $\mathrm{I}(2)$ & $12(6)$ & I (4) & $2(12)$ \\
\hline History of sleeping pill use & $138(18)$ & $56(12)$ & $9(2 I)$ & $64(3 I)$ & $7(26)$ & $2(12)$ \\
\hline History of inhalant use & $130(17)$ & $53(11)$ & $8(19)$ & $57(27)$ & $9(33)$ & $3(18)$ \\
\hline History of injection drug use & $199(26)$ & $43(9)$ & $4(9)$ & $134(64)$ & $15(56)$ & $3(18)$ \\
\hline History of incarceration & $303(39)$ & $122(26)$ & $17(40)$ & 144 (69) & $16(59)$ & $4(24)$ \\
\hline \multicolumn{7}{|l|}{ High-risk sexual practices } \\
\hline $\begin{array}{l}\text { Have }>4 \text { sex partners in past } \\
6 \text { months }\end{array}$ & $9(1)$ & $5(1)$ & I (2) & $2(1)$ & I (4) & $0(0)$ \\
\hline Not always use condom* & $247(74)$ & $|5|(73)$ & $13(59)$ & $67(77)$ & $6(67)$ & $10(100)$ \\
\hline $\begin{array}{l}\text { Have sex with a sex worker } \\
\text { in past } 6 \text { months* }\end{array}$ & $29(4)$ & $17(4)$ & $3(7)$ & $7(4)$ & $2(7)$ & $0(0)$ \\
\hline \multicolumn{6}{|l|}{ Laboratory studies } & $2(17)$ \\
\hline $\begin{array}{l}\text { Aspartate aminotransferase } \geq \\
\text { I } 20 \text { units/L }\end{array}$ & $67(9)$ & $35(7)$ & $7(16)$ & $18(9)$ & $4(15)$ & $3(18)$ \\
\hline $\begin{array}{l}\text { Alanine aminotransferast } \geq \\
\text { 165 units/L }\end{array}$ & $17(2)$ & $10(2)$ & $2(5)$ & $3(1)$ & I (4) & I (6) \\
\hline Bilirubin $>2 \mathrm{mg} / \mathrm{dL}$ & $77(10)$ & $50(\mathrm{II})$ & $6(14)$ & $14(7)$ & $4(15)$ & $3(18)$ \\
\hline $\begin{array}{l}\text { CD4+ T-lymphocyte* (cells/ } \\
\mu \mathrm{L} \text { ), median (range) }\end{array}$ & $63(0-93)$ & $53(0-750)$ & $4 I(I-675)$ & $76(0-823)$ & $101(1-893)$ & $139(18-552)$ \\
\hline \multicolumn{7}{|l|}{$\begin{array}{l}\text { Medicines taken during } \\
\text { TB treatment }\end{array}$} \\
\hline Co-trimoxazole & $665(87)$ & $4 \mid I(87)$ & $39(91)$ & $|8|(86)$ & $22(82)$ & $12(7 \mid)$ \\
\hline
\end{tabular}


Table I: Characteristics and clinical features of HIV-infected TB patients at the time of TB diagnosis, stratified by markers for viral hepatitis infection. (Continued)

\begin{tabular}{|c|c|c|c|c|c|c|}
\hline Fluconazole & $454(59)$ & $309(66)$ & $27(63)$ & $100(48)$ & II (4I) & $7(4 I)$ \\
\hline Anti-retroviral therapy & $328(43)$ & $247(52)$ & $25(58)$ & $48(23)$ & $5(19)$ & $3(18)$ \\
\hline
\end{tabular}

TB, tuberculosis; HIV, human immunodeficiency virus; HRZE, isoniazid, rifampin, pyrazinamide, ethambutol; DOT, directly observed therapy; $\mathrm{HBsAg}$, hepatitis $\mathrm{B}$ surface antigen; $\mathrm{HCV}$, hepatitis $\mathrm{C}$ virus

*Among those with available data/results

compared to non-reactive), and 69/465 (15\%) patients that were non-reactive.

\section{Risk factors for HBsAg andlor anti-HCV reactivity}

Factors independently associated with HBsAg reactivity included being a man who had sex with men (adjusted odds ratio [AOR], 2.1; 95\% confidence interval [CI], 1.14.3 ) and having low TB knowledge (AOR, 1.8; 95\% CI, 1.0-3.0; Table 2.1). Factors independently associated with anti-HCV reactivity were being unemployed (AOR, 1.7; 95\% CI, 1.1-2.5), having high TB stigma (AOR, 1.7; 95\% CI, 1.0-2.7), currently smoking (AOR, 1.7; 95\% CI, 1.0-2.9), having injection drug use history (AOR, 12.8; 95\% CI, 7.0-23.2), and living in Bangkok (AOR, 15.8; 95\% CI, 9.4-26.5; Table 2.2). Two factors were independently associated with having both HBsAg and anti-HCV reactivity: having injection drug use history (AOR, 3.2; 95\% CI, 1.0-9.8) and living in Bangkok (AOR, 2.7; 95\% CI, 1.1-6.6; Table 2.3).

\section{TB treatment and outcomes}

A standard first-line TB regimen (two months of isoniazid, rifampin, pyrazinamide, and ethambutol followed by at least four months of isoniazid and rifampin) was used in $665(87 \%)$ patients. Co-trimoxazole, fluconazole, and anti-retroviral therapy (ART) were taken by $665(86 \%)$, 454 (59\%), and 328 (43\%), respectively, during TB treatment. The total follow-up time was 428 person-years. Four hundred and ninety-three patients (64\%) were successfully treated (Table 3 ). Of the remaining patients, 6 (1\%) failed treatment, $130 \quad(17 \%)$ died, 65 (9\%) defaulted, $70(9 \%)$ transferred out, and $5(1 \%)$ were still on treatment at the time follow-up ended.

At least one adverse event occurred in 236 (31\%) patients. The most common adverse events occurring during $\mathrm{TB}$ treatment (Table 3) were rash (15\%), followed by immune reconstitution inflammatory syndrome $(7 \%)$, liver disease (5\%), diarrhea (5\%), pneumonia (4\%), meningitis (3\%), HIV wasting syndrome (3\%), cryptococcosis $(2 \%)$, herpes zoster $(2 \%)$, and recurrent upper respiratory infections or sinusitis (1\%).

\section{Impact of viral hepatitis on adverse events and treatment outcomes}

HIV wasting syndrome and upper respiratory infections or sinusitis occurring during TB treatment were the only health conditions significantly associated with markers of viral hepatitis infection $(\mathrm{p}=0.02$ and $\mathrm{p}=0.05$, respectively). Upper respiratory infections or sinusitis was reported by $7 \%$ of patients reactive to HBsAg and anti$\mathrm{HCV}, 1 \%$ of patients non-reactive to any viral markers, and none in other groups. HIV wasting syndrome was reported in nearly $12 \%$ of patients with missing viral hepatitis markers, but in $4 \%$ of all other groups.

We analyzed the odds of death compared with successful TB treatment, stratified by markers of viral hepatitis infection and adjusted for factors known to be associated with TB treatment outcome. There was no difference in the odds of death for patients HBsAg reactive, anti-HCV reactive, or HBsAg and anti-HCV reactive, compared with patients non-reactive to any viral marker (Table 4.1). The findings were not significantly different when we analyzed all TB patients and only culture-confirmed patients. Factors adjusted for in this analysis included TB disease severity, HIV disease severity (i.e., CD4 count at time of enrollment), co-trimoxazole use, fluconazole use, antiretroviral use, directly observed therapy use, hospitalization at enrollment, and previous TB treatment.

We analyzed the odds of either death or default compared with successful TB treatment, stratified by viral hepatitis markers and adjusted for factors known to be associated with TB treatment outcome as noted above. Among patients HBsAg reactive, the odds of death or default was 2.7 (95\% CI, 1.1-6.4) compared with patients non-reactive to any viral marker. This difference was also seen in the subset of culture-confirmed TB patients (Table 4.2). The odds of death or default was also increased in patients anti-HCV reactive, but this was only found in the subset of patients with culture-confirmed TB. Adjusting for injection drug use did not change the findings from these analyses.

\section{Discussion}

Among HIV-infected TB patients living in Thailand, markers of viral hepatitis infection, particularly hepatitis C virus, were common and strongly associated with known behavioral risk factors. Viral hepatitis markers were not strongly associated with death or the development of clinical hepatitis during TB treatment.

The rate of HBsAg seropositivity in HIV-infected TB patients was similar to that found in the general Thai population.[15] In future years, the rate of HBV infection is 
Table 2: Univariate and multivariate logistic regression analyses of risk factors for viral hepatitis infections among HIV-infected TB patients.

\begin{tabular}{|c|c|c|c|c|c|c|c|c|}
\hline \multicolumn{9}{|c|}{ I. Risk factors for $\mathrm{HBsAg}$ reactive $(n=732)$} \\
\hline \multirow[t]{2}{*}{ Risk factors } & \multirow[t]{2}{*}{ OR } & \multicolumn{2}{|c|}{$95 \% \mathrm{Cl}$} & \multirow[t]{2}{*}{$P$} & \multirow[t]{2}{*}{ AOR } & \multicolumn{2}{|c|}{$95 \% \mathrm{Cl}$} & \multirow[t]{2}{*}{$\mathrm{P}$} \\
\hline & & L & $u$ & & & $\mathrm{~L}$ & $u$ & \\
\hline Male & 2.0 & I.I & 3.7 & 0.03 & 1.6 & 0.8 & 3.1 & 0.16 \\
\hline Man having sex with men & 2.3 & 1.2 & 4.6 & 0.02 & 2.1 & I.I & 4.3 & 0.04 \\
\hline Low TB knowledge & 1.6 & 0.9 & 2.8 & 0.08 & 1.8 & 1.0 & 3.0 & 0.04 \\
\hline History of inhalant use & 1.7 & 0.9 & 3.0 & 0.08 & 1.4 & 0.7 & 2.7 & 0.29 \\
\hline History of incarceration (jail) & 1.4 & 0.9 & 2.3 & 0.20 & 1.2 & 0.7 & 2.0 & 0.62 \\
\hline Had $>4$ sex partners in past 6 months & 2.8 & 0.6 & 13.9 & 0.20 & 1.9 & 0.4 & 9.4 & 0.46 \\
\hline \multicolumn{9}{|c|}{ 2. Risk factors for anti-HCV reactive $(n=736)$} \\
\hline \multirow[t]{2}{*}{ Risk factors } & OR & \multicolumn{2}{|c|}{$95 \% \mathrm{Cl}$} & $P$ & AOR & \multicolumn{2}{|c|}{$95 \% \mathrm{Cl}$} & $P$ \\
\hline & & L & $u$ & & & $\mathrm{~L}$ & $u$ & \\
\hline Male & 3.1 & 2.1 & 4.7 & $<0.01$ & 1.4 & 0.8 & 2.5 & 0.25 \\
\hline Age $>34$ years & 1.3 & 1.0 & 1.8 & 0.09 & 1.2 & 0.8 & 2.0 & 0.37 \\
\hline Unemployed & 1.7 & 1.3 & 2.5 & $<0.01$ & 1.7 & I.I & 2.5 & 0.03 \\
\hline High TB stigma & 1.4 & 1.0 & 2.0 & 0.04 & 1.7 & 1.0 & 2.7 & 0.04 \\
\hline Currently smoke & 2.7 & 1.9 & 3.8 & $<0.01$ & 1.7 & 1.0 & 2.9 & 0.04 \\
\hline History of alcohol use & 1.5 & I.I & 2.1 & 0.03 & 1.0 & 0.6 & 1.7 & 0.92 \\
\hline History of methamphetamine use & 3.6 & 2.6 & 5.0 & $<0.01$ & 0.7 & 0.4 & 1.3 & 0.32 \\
\hline History of marijuana use & 3.9 & 2.8 & 5.5 & $<0.01$ & 1.4 & 0.8 & 2.5 & 0.30 \\
\hline History of ketamine use & 2.3 & 1.0 & 5.1 & 0.05 & 0.9 & 0.2 & 4.2 & 0.86 \\
\hline History of ecstasy use & 1.7 & 0.8 & 3.6 & 0.15 & 1.1 & 0.3 & 4.9 & 0.88 \\
\hline History of sleeping pill use & 3.0 & 2.1 & 4.4 & $<0.01$ & 1.1 & 0.6 & 2.0 & 0.84 \\
\hline History of inhalant use & 2.9 & 2.0 & 4.3 & $<0.01$ & 0.9 & 0.5 & 1.7 & 0.68 \\
\hline History of injection drug use & 17.2 & 11.5 & 25.6 & $<0.01$ & 12.8 & 7.0 & 23.2 & $<0.01$ \\
\hline History of incarceration (jail) & 5.6 & 4.0 & 7.8 & $<0.01$ & 1.3 & 0.8 & 2.3 & 0.35 \\
\hline Live in Bangkok & 15.3 & 10.2 & 23.1 & $<0.01$ & 15.8 & 9.4 & 26.5 & $<0.01$ \\
\hline \multicolumn{9}{|c|}{ 3. Risk factors for $\mathrm{HBsAg}$ and anti-HCV reactive $(n=740)$} \\
\hline \multirow[t]{2}{*}{ Risk factors } & OR & \multicolumn{2}{|c|}{$95 \% \mathrm{Cl}$} & $P$ & AOR & \multicolumn{2}{|c|}{$95 \% \mathrm{Cl}$} & $P$ \\
\hline & & L & $u$ & & & $\mathrm{~L}$ & $U$ & \\
\hline Male & 5.6 & 1.3 & 23.8 & 0.02 & 3.2 & 0.7 & 14.4 & 0.14 \\
\hline History of methamphetamine use & 2.1 & 0.9 & 4.6 & 0.07 & 0.7 & 0.2 & 2.2 & 0.54 \\
\hline History of marijuana use & 1.9 & 0.9 & 4.2 & 0.11 & 0.8 & 0.3 & 2.4 & 0.69 \\
\hline History of inhalant use & 2.7 & 1.2 & 6.2 & 0.02 & 1.9 & 0.7 & 5.4 & 0.21 \\
\hline History of injection drug use & 4.5 & 2.0 & 10.2 & $<0.01$ & 3.2 & 1.0 & 9.8 & 0.05 \\
\hline History of incarceration (jail) & 2.3 & 1.0 & 4.9 & 0.04 & 1.0 & 0.3 & 3.3 & 0.97 \\
\hline Live in Bangkok & 3.2 & 1.5 & 7.0 & $<0.01$ & 2.7 & 1.1 & 6.6 & 0.03 \\
\hline
\end{tabular}

TB, tuberculosis; HIV, human immunodeficiency virus; OR, odds ratio; $A O R$, adjusted odds ratio; $\mathrm{Cl}$, confidence interval; L, lower bound; $U$, upper bound; $\mathrm{HBsAg}$, hepatitis $B$ surface antigen; Variables for which $\mathrm{p}=0.20$ in univariate analyses were included in multivariate logistic regression analysis

likely to decline considerably, because universal hepatitis B childhood vaccination was integrated into the national expanded program on immunization in 1992.[16] Among HIV-infected TB patients, the strongest association with HBV infection was being a man having sex with men.
In contrast to previous studies, we did not find an association between high-risk sexual practices (e.g., not using a condom, multiple partners) and HBsAg seropositivity, possibly because our sexual history questions probed only recent behavior and patients were generally quite 
Table 3: Most common adverse events during TB treatment and treatment outcomes among HIV-infected TB patients, stratified by markers for viral hepatitis infections.

\begin{tabular}{|c|c|c|c|c|c|c|}
\hline \multirow{3}{*}{$\begin{array}{l}\text { Adverse events } \\
\text { and treatment } \\
\text { outcomes }\end{array}$} & \multirow{2}{*}{$\begin{array}{l}\text { All patients } \\
(\mathrm{n}=769)\end{array}$} & \multirow{2}{*}{$\begin{array}{l}\text { Non-reactive for } \\
\mathrm{HBsAg} \text { and anti- } \\
\mathrm{HCV}(\mathrm{n}=472)\end{array}$} & \multicolumn{3}{|c|}{ Reactive for } & \multirow[t]{2}{*}{ Unknown $(n=17)$} \\
\hline & & & $\begin{array}{l}\text { Only HBsAg } \\
(n=43)\end{array}$ & $\begin{array}{l}\text { Only anti-HCV } \\
(n=210)\end{array}$ & $\begin{array}{l}\mathrm{HBsAg} \text { and anti- } \\
\mathrm{HCV}(\mathrm{n}=27)\end{array}$ & \\
\hline & n (\%) & n (\%) & n (\%) & n (\%) & n (\%) & n (\%) \\
\hline \multicolumn{7}{|l|}{ Adverse events } \\
\hline Rash & $116(15)$ & $69(15)$ & $7(16)$ & $32(15)$ & $4(15)$ & $4(24)$ \\
\hline $\begin{array}{l}\text { Immune } \\
\text { reconstitution } \\
\text { inflammatory } \\
\text { syndrome* }\end{array}$ & $16(7)$ & $12(7)$ & $0(0)$ & $2(6)$ & $I(13)$ & $I(100)$ \\
\hline Liver disease & $4 \mid(5)$ & $23(5)$ & $3(7)$ & $12(6)$ & $2(7)$ & I (6) \\
\hline Diarrhea & $36(5)$ & $22(5)$ & $2(5)$ & $7(3)$ & $2(7)$ & $3(18)$ \\
\hline $\begin{array}{l}\text { Pneumonia } \\
\text { including PCP }\end{array}$ & $30(4)$ & $15(3)$ & $2(5)$ & II (5) & I (4) & I (6) \\
\hline Meningitis & $20(3)$ & II (2) & $2(5)$ & $6(3)$ & I (4) & $0(0)$ \\
\hline $\begin{array}{l}\text { HIV wasting } \\
\text { syndrome }\end{array}$ & $19(3)$ & $15(3)$ & $0(0)$ & $I(I)$ & I (4) & $2(12)$ \\
\hline Cryptococcosis & $16(2)$ & $8(2)$ & $0(0)$ & $8(4)$ & $0(0)$ & $0(0)$ \\
\hline Herpes zoster & $12(2)$ & $5(1)$ & $2(5)$ & $4(2)$ & I (4) & $0(0)$ \\
\hline $\begin{array}{l}\text { Recurrent upper } \\
\text { respiratory } \\
\text { infections or } \\
\text { sinusitis }\end{array}$ & $7(1)$ & $5(1)$ & $0(0)$ & $0(0)$ & $2(7)$ & $0(0)$ \\
\hline \multicolumn{7}{|l|}{$\begin{array}{l}\text { Treatment } \\
\text { outcomes }\end{array}$} \\
\hline Cure & $210(27)$ & $133(28)$ & $7(16)$ & $63(30)$ & $6(22)$ & I (6) \\
\hline Complete & $283(37)$ & $190(40)$ & $16(37)$ & $65(31)$ & $9(33)$ & $3(18)$ \\
\hline Failure & $6(1)$ & $3(I)$ & I (2) & $2(1)$ & $0(0)$ & $0(0)$ \\
\hline Die & $130(17)$ & $72(15)$ & $5(12)$ & $37(18)$ & $7(26)$ & $9(53)$ \\
\hline Default & $65(9)$ & $34(7)$ & $8(19)$ & $20(10)$ & I (4) & $2(12)$ \\
\hline Transfer out & $70(9)$ & $37(8)$ & $5(12)$ & $22(11)$ & $4(15)$ & $2(12)$ \\
\hline On treatment & $5(1)$ & $3(1)$ & I (2) & $I(I)$ & $0(0)$ & $0(0)$ \\
\hline
\end{tabular}

TB, tuberculosis; HIV, human immunodeficiency virus; $\mathrm{HBs} A$ g, hepatitis $B$ surface antigen; $\mathrm{HCV}$, hepatitis $\mathrm{C}$ virus; PCP, pneumocystis carinii pneumonia.

*Among 237 patients eligible to be evaluated only.

ill. $[19,20]$ Men who have sex with men are at high risk of HIV in Thailand, and the prevalence of HIV infection has risen dramatically in recent years.[21] This population, therefore, will increasingly require healthcare personnel sufficiently trained and equipped to manage concomitant HIV, TB, and viral hepatitis infection. We found that HBsAg seropositive patients were more likely to have elevated liver function enzymes, but, in contrast to studies in other settings, we found that TB treatment was well-tolerated, with rates of acquired hepatitis and other adverse events similar to patients not HBsAg seropositive.[22,23] Rates of default, however, were higher in this population, suggesting that further research is needed to explore whether medication intolerance and occult hepatitis could be factors leading to $\mathrm{TB}$ treatment default.
Antibodies to HCV were found in nearly one-third of patients, and nearly two-thirds of these cases reported a history of injection drug use. Other independent risk factors included living in Bangkok and smoking; given the known association between HCV infection and injection drug use[24], it is possible that living in Bangkok and smoking were surrogate markers for patients that did not accurately disclose their injection drug use history. We found that TB patients with HCV and HIV infection had adverse event rates and treatment outcomes no worse than TB patients with only HIV infection. Further research is needed to confirm this finding in other countries and in populations whose HCV infection is better characterized through measurement of HCV viral load, HCV genotype, and pathological evidence of liver disease. 
Table 4: Adjusted odds ratio for death and/or default outcomes among HIV-infected TB patients.

\begin{tabular}{|c|c|c|c|c|c|c|c|c|}
\hline \multicolumn{9}{|c|}{ I. Those with cure, complete, death outcomes } \\
\hline \multirow[t]{3}{*}{ Comparison groups versus non-reactive } & \multicolumn{4}{|c|}{ All patients } & \multicolumn{4}{|c|}{ Culture-confirmed TB } \\
\hline & \multirow[t]{2}{*}{$\mathrm{n}$} & \multirow[t]{2}{*}{ AOR } & \multicolumn{2}{|c|}{$95 \% \mathrm{Cl}$} & \multirow[t]{2}{*}{$\mathrm{n}$} & \multirow[t]{2}{*}{ AOR } & \multicolumn{2}{|c|}{$95 \% \mathrm{Cl}$} \\
\hline & & & $\mathrm{L}$ & $U$ & & & $\mathrm{~L}$ & $U$ \\
\hline $\mathrm{HBsAg}+$ & 385 & 1.0 & 0.3 & 3.3 & 188 & 0.5 & 0.1 & 4.9 \\
\hline Anti-HCV + & 504 & 1.1 & 0.6 & 1.9 & 253 & 1.4 & 0.6 & 3.6 \\
\hline $\mathrm{HBsAg}$ and anti-HCV + & 374 & 2.1 & 0.6 & 7.6 & 185 & 4.8 & 0.5 & 42.9 \\
\hline \multicolumn{9}{|c|}{ 2. Those with cure, complete, death, and default outcomes } \\
\hline \multirow[t]{3}{*}{ Comparison groups versus non-reactive } & \multicolumn{4}{|c|}{ All patients } & \multicolumn{4}{|c|}{ Culture-confirmed TB } \\
\hline & \multirow[t]{2}{*}{$\mathrm{n}$} & AOR & \multicolumn{2}{|c|}{$95 \% \mathrm{Cl}$} & $\mathrm{n}$ & AOR & \multicolumn{2}{|c|}{$95 \% \mathrm{Cl}$} \\
\hline & & & $\mathrm{L}$ & $U$ & & & $\mathrm{~L}$ & $U$ \\
\hline $\mathrm{HBsAg}+$ & 420 & 2.7 & 1.1 & 6.4 & 207 & 5.5 & 1.4 & 21.9 \\
\hline Anti-HCV + & 549 & 1.2 & 0.8 & 2.0 & 281 & 2.0 & 1.0 & 4.0 \\
\hline $\mathrm{HBsAg}$ and anti-HCV + & 401 & 1.4 & 0.4 & 4.7 & 198 & 1.7 & 0.3 & 11.2 \\
\hline
\end{tabular}

+ sign indicates reactive; bold type indicates statistical significance $(\mathrm{P}<0.05)$; TB, tuberculosis, HIV, human immunodeficiency virus; AOR, adjusted odds ratio; $\mathrm{Cl}$, confidence interval; $\mathrm{L}$, lower bound; $\mathrm{U}$, upper bound; $\mathrm{HBs} \mathrm{Ag}$, hepatitis $\mathrm{B}$ surface antigen; $\mathrm{HCV}$, hepatitis $\mathrm{C}$ virus, $\mathrm{N}$, number of patients included in the model.

*Adjusted odds ratios from multivariate logistic regression analyses adjusted for TB disease severity, HIV disease severity, co-trimoxazole use, fluconazole use, anti-retroviral use, whether or not received directly observed therapy, hospitalized at enrollment and been treated for TB previously

Our study is subject to important limitations. First, we only performed limited laboratory testing on patients. Confirmatory tests, other serological markers of viral hepatitis, and viral load levels were not performed. Only a small proportion of those who become HBV infected will remain HBsAg positive; thus, factors associated with HBsAg positivity may be risk factors for $\mathrm{HBV}$ infection or determinants of chronic HBV disease. Serologic testing was also done in different laboratories using different commercial assays. Second, patients were only required to have liver function tests measured at the beginning of treatment. Our estimates of acquired hepatitis were based on persons who remained on TB treatment, had symptoms, sought care, and had a clinician diagnose clinical hepatitis. The incidence of clinical hepatitis developing during ТВ treatment, therefore, could be substantially higher than what we have reported, given the large number of patients that defaulted, transferred out, and died during treatment. The same limitation applies to our ascertainment of all adverse events. Finally, our sample size of patients may have been too small to detect low levels of hepatotoxicity, and the population we studied may not be representative of all HIV-infected TB patients in Thailand.

\section{Conclusion}

The global burden of TB has risen dramatically in the past ten years due to the HIV epidemic. While HCV rates have similarly increased, the impact of viral hepatitis on the TB/ HIV syndemic is less clear. This study provides important insight into the burden of viral hepatitis infection among HIV-infected TB patients living in Thailand, and demon- strates the need for further epidemiologic and clinical studies to optimize the management of this complicated medical condition.

\section{Competing interests}

The authors declare that they have no competing interests.

\section{Authors' contributions}

CS designed the study, collected data, and helped draft the manuscript. WK analyzed data and helped draft the manuscript. DP, PC, PL, LS, SN, SA, SL, WS, and CB helped design the study and collect data. JKV designed the study, analyzed data, and drafted the manuscript. All authors revised the draft manuscript and then approved the final version.

\section{Acknowledgements}

We are greatly indebted to all participants in our study. We thank the staff from Thailand Ministry of Public Health - U.S. Centers for Disease Control and Prevention, Department of Health, Bangkok Metropolitan Administration Administration, and from TB treatment facilities in Bangkok, Phuket, Ubon Ratchathani provinces and at Bamrasnaradura Infectious Diseases Institute in Nonthaburi

This project was funded by the U.S. Agency for International Development. The funding agency had no role in study design, conduct, data analysis, or manuscript preparation. The findings and conclusions in this report are those of the authors and do not necessarily represent the official views of U.S. CDC.

\section{References}

I. Onyebujoh PC, Ribeiro I, Whalen CC: Treatment options for HIV-associated tuberculosis. J Infect Dis 2007, 196 Suppl I:S35-5. 
2. Yee D, Valiquette C, Pelletier M, Parisien I, Rocher I, Menzies D: Incidence of serious side effects from first-line antituberculosis drugs among patients treated for active tuberculosis. $\mathrm{Am} \mathrm{J}$ Respir Crit Care Med 2003, 167:1472-I477.

3. Dean GL, Edwards SG, Ives NJ, Matthews G, Fox EF, Navaratne L, Fisher M, Taylor GP, Miller R, Taylor CB, de Ruiter A, Pozniak AL: Treatment of tuberculosis in HIV-infected persons in the era of highly active antiretroviral therapy. AIDS 2002, 16:75-83.

4. Jain MK: Drug-induced liver injury associated with HIV medications. Clin Liver Dis 2007, I I:6 I5-639.

5. Jamisse L, Balkus J, Hitti J, Gloyd S, Manuel R, Osman N, Djedje M, Farquhar C: Antiretroviral-associated toxicity among HIV-Iseropositive pregnant women in Mozambique receiving nevirapine-based regimens. J Acquir Immune Defic Syndr 2007, 44:37I-376.

6. Breton G, Adle-Biassette H, Therby A, Ramanoelina J, Choudat L, Bissuel $F$, Huerre M, Dromer F, Dupont B, Lortholary O: Immune reconstitution inflammatory syndrome in HIV-infected patients with disseminated histoplasmosis. AIDS 2006, 20:119-121.

7. Hu DJ, Subbarao S, Vanichseni S, Mock PA, van Griensven F, Nelson R, Nguyen L, Kitayaporn D, Young NL, Des Jarlais D, Byers RJ, Choopanya K, Mastro TD: Higher viral loads and other risk factors associated with HIV-I seroconversion during a period of high incidence among injection drug users in Bangkok. J Acquir Immune Defic Syndr 2002, 30:240-247.

8. Dolan K, Kite B, Black E, Aceijas C, Stimson GV, Reference Group on HIVIAIDS Prevention and Care among Injecting Drug Users in Developing and Transitional Countries: HIV in prison in low-income and middle-income countries. Lancet Infect Dis 2007, 7:32-4I.

9. Drug injection and HIVIAIDS in Asia [http://www.mapnet work.org/docs/MAP IDU\%20Book\%2024Jun05 en.pdf]

10. Padmapriyadarsini C, Chandrabose J, Victor L, Hanna LE, Arunkumar $\mathrm{N}$, Swaminathan S: Hepatitis B or hepatitis C co-infection in individuals infected with human immunodeficiency virus and effect of anti-tuberculosis drugs on liver function. J Postgrad Med 2006, 52:92-96.

II. Ungo JR, Jones D, Ashkin D, Hollender ES, Bernstein D, Albanese AP, Pitchenik AE: Antituberculosis drug-induced hepatotoxicity. The role of hepatitis $C$ virus and the human immunodeficiency virus. Am J Respir Crit Care Med 1998, 157(6 Pt I): $187 \mid-1876$

12. Hill K, Vapattanawong P, Prasartkul P, Porapakkham Y, Lim SS, Lopez $A D$ : Epidemiologic transition interrupted: a reassessment of mortality trends in Thailand, 1980-2000. Int J Epidemiol 2006, 36:374-384.

13. World Health Organization: Global tuberculosis control: surveillance, planning, financing. WHO report 2007. Geneva, World Health Organization; 2007.

14. Jittimanee SX, Wiriyakitjar D, Jittimanee S, Nateniyom S, Kaophaithool S, Varma JK: Provider-initiated HIV testing and counseling in tuberculosis clinics in Thailand. Int J Tuberc Lung Dis 2008 in press.

15. Nantachit N, Robison V, Wongthanee A, Kamtorn N, Suriyanon V, Nelson KE: Temporal trends in the prevalence of HIV and other transfusion-transmissible infections among blood donors in northern Thailand, 1990 through 2001. Transfusion 2003, 43:730-735.

16. Chongsrisawat $\mathrm{V}$, Yoocharoen $\mathrm{P}$, Theamboonlers $\mathrm{A}$, Tharmaphornpilas P, Warinsathien P, Sinlaparatsamee S, Paupunwatana S, Chaiear K, Khwanjaipanich S, Poovorawan $Y$ : Hepatitis B seroprevalence in Thailand: 12 years after hepatitis $B$ vaccine integration into the national expanded programme on immunization. Trop Med Int Health 2006, I I: 1496-1502.

17. Songsivilai S, Jinathongthai S, Wongsena W, Tiangpitayakorn C, Dharakul T: High prevalence of hepatitis $\mathbf{C}$ infection among blood donors in northeastern Thailand. Am J Trop Med Hyg 1997, 57:66-69.

18. National TB program guidelines. Bangkok, TB Cluster, Bureau of AIDS, TB and STIs, Department of Diseases Control, Ministry of Public Health; 2005.

19. Neaigus A, Gyarmathy VA, Zhao M, Miller M, Friedman SR, Des Jarlais DC: Sexual and other noninjection risks for HBV and HCV seroconversions among noninjecting heroin users. J Infect Dis 2007, 195:|052-|06|.
20. Neaigus A, Gyarmathy VA, Miller M, Frajzyngier V, Zhao M, Friedman SR, Des Jarlais DC: Injecting and sexual risk correlates of HBV and HCV seroprevalence among new drug injectors. Drug Alcohol Depend 2007, 89:234-243.

21. Centers for Disease Control and Prevention: HIV prevalence among populations of men who have sex with men--Thailand, 2003 and 2005. MMWR Morb Mortal Wkly Rep 2006, 55:844-848.

22. Hoffmann CJ, Charalambous S, Thio CL, Martin DJ, Pemba L, Fielding $\mathrm{KL}$, Churchyard G], Chaisson RE, Grant AD: Hepatotoxicity in an African antiretroviral therapy cohort: the effect of tuberculosis and hepatitis B. AIDS 2007, 21:130I-I308.

23. Pan L, Jia ZS, Chen L, Fu EQ, Li GY: Effect of anti-tuberculosis therapy on liver function of pulmonary tuberculosis patients infected with hepatitis B virus. World J Gastroenterol 2005, I I:25I8-252I.

24. Kittikraisak W, Davidson PJ, Hahn JA, Lum PJ, Evans JL, Moss AR, Page-Shafer K: Incarceration among young injectors in San Francisco: associations with risk for hepatitis C virus infection. J Subst Use 2006, I I:27I-28I.

\section{Pre-publication history}

The pre-publication history for this paper can be accessed here:

http://www.biomedcentral.com/1471-2458/8/245/pre pub

Publish with Bio Med Central and every scientist can read your work free of charge

"BioMed Central will be the most significant development for disseminating the results of biomedical research in our lifetime. "

Sir Paul Nurse, Cancer Research UK

Your research papers will be:

- available free of charge to the entire biomedical community

- peer reviewed and published immediately upon acceptance

- cited in PubMed and archived on PubMed Central

- yours - you keep the copyright
BioMedcentral 